\title{
Risk Management and Forecasting Macro-Variables Influences on Bank Risk
}

\author{
Hashem Valipour ${ }^{1} \&$ Mostafa Sohouli Vahed ${ }^{2}$ \\ ${ }^{1}$ Associate Professor, Department of Accounting, Faculty Members of Islamic Azad University, Firozabad, Iran \\ ${ }^{2} \mathrm{PhD}$ Student of Accounting, Islamic Azad University, Yasuj, Iran \\ Correspondence: Hashem Valipour, Associate Professor, Department of Accounting, Faculty Members of Islamic \\ Azad University, Firozabad, Iran. E-mail: h.valipour@gmail.com
}

Received: March 18, 2017

Accepted: April 30, 2017

Online Published: May 17, 2017

doi:10.5539/ijbm.v12n6p137

URL: https://doi.org/10.5539/ijbm.v12n6p137

\begin{abstract}
Nowadays banks, as the most important component ofmoney market, are playing a very important role in country's economy. By developing money markets, banking and financial institutes' activities it is extensively developed and with no doubts economic development is not possible without considering the role of banking and money markets. By virtue of special and sensitive role of banks in Iran economic system, any shock, disturbances and/or ineffectiveness in economic systems directly effect on banks' and financial institutes' performance as well as phenomenon such as high inflation and/or price shocks and fluctuations in other markets such as currencies shall directly and indirectly effect on banks' risk and profitability. Hence in this paper the effects of economic macro variables on capital adequacy, liquidity risk and credit risk of banks have been reviewed. The results show that there is a positive and significant relationship between gross domestic product (GDP), petroleum revenue, and exchange rate oncapital adequacy of banks. But the effects of liquidity and inflation on capital adequacy of banks are negative and significant which means it causes decreasing of capital adequacy of banks. Increasing in the variables of petroleum revenue, liquidity and inflation result in increasing of liquidity risk and vice versa the increasing in variables of GDP and exchange rate decreased the liquidity risk. Petroleum revenue, liquidity and inflation increments cause increasing in banks' credit risk as well as GDP and exchange rate increments result in decreasing in banks' credit risk.
\end{abstract}

Keywords: liquidity risk, credit risk, capital adequacy, macro-economics

\section{Introduction}

Nowadays banks, as the most important component of money market, are playing a very important role in our country's economy. By developing money markets, banking and financial institutes' activities, it is extensively developed and with no doubts economic development is not possible without considering the role of banking and money markets.

Bank is the main financier of economic real sectors (industry, agriculture and public services). Besides its main function, the main goal of bank, like other business institutes, is optimized providing and allocating of resources, offering a variety of services to customers and profitability.

Banks are faced different risks in their daily operations. These risks are categorized to 4 different groups: 1) financial risks; 2) operational risks; 3) business risks; and 4) event risks (Greuning \& Bratanovic, 2000).

Financial risks include two main groups:

A) Net risks include liquidity risk, credit risk and bankruptcy risk which result in irreparable losses if they aren't correctly managed.

B) Speculation risks which are formed according to financial arbitrages. If arbitrage is done correctly, it will cause high profit and otherwise results in high loss. This group of risks includes interest rate risk, exchange rate risk and market situation risk.

Financial risk causes enhancing the whole bank risk through banking complex relationships (in economic system).

So risks should be predictable and it is useful for banks policies to aware about changes in bank risks. Bank risks 
are affected by economic macro-variables and this paper tries to follow this object.

According to ongoing changes in environmental factors and economic systems, everyday different risk influence financial structure of different institutes. Institutes such as financial ones and even governments are faced special risks depending on their performance domain.

Risk is a threat which makes opportunity to gain success and profit. In Longman dictionary, risk is a possibility that something may be lost, harmed, or damaged; or that something bad, unpleasant, or dangerous may happen. On the other hand risk can be the possibility of don't meeting our further predictions.

In latest decades the banking crisis because of deposits run off, increasing accrued debits of banks, economic downturn, etc. in industrial countries and especially in under development countries resulted in disorders of financial markets discipline and making bankruptcy of many banks. According to the reviews the main reason of this matter has been recognized as capital inadequacy of banks. Hence it is important to consider risk and its management (Hemati \& MohebiNezhad, 2009, p. 35).

Cash management is also one the greatest challenges which banking system is faced. The main reason of this challenge is that more banks are financed from shore-term deposits. Furthermore the loans and bank credits are spent in asset investments which have low level liquidity.

The main duty of banks is balancing between short-term financial accruals and long-term investments. Banks are faced to bankruptcy and failure to meet the obligations if they keep inadequate cash. Keeping plenty of cashes is also again ineffective allocation of resources which causes decreasing interest rate and consequently losing the market.

Another risk that financial institutes are faced is uncollectible loans of customers which affected by economic situations.

Non-financial risks have so much effect on financial risk; that is any non-financial risk makes eventually changes in financial variables. For example in case of management issues there is a credit risk for an organization. Political risks also simply cause changes in exchange rate. In fact the changes in financial variables depend on several factors and whereas in most of situation market behavior is not simply predictable, changes in financial variables are also not ease to predict. Even sensitivity rate of these variables against the changes in other factors varies in different situations and periods.

In this research it is tried to verify the effects of economic macro-variables including GDP, petroleum incomes, liquidity growth rate, inflation rate and exchange rate on capital adequacy, liquidity risks and credit risks of banks.

\section{Risk Management}

One of the common definitions of management is: "the process of fulfilling predetermined duties". Hence the aim of risk management is also reaching predetermined goals with respect to risk affairs. This matter means that there should be certain criteria in an organization such as profit and non-profit to control -if may not be completely removed- unfavorable effects of the organization's activities. So the processes of identifying, measuring, monitoring and controlling organization's activities under risk management are so important.

Risk management has been considered by organizations because of following events:

- On February 1995, Baring Bank's incident shocked the market and caused downfall of the oldest commercial bank of GB. The reasons of this disaster included improper regulations, executive methods and lax systems. All risk management factors such as market risk, credit risk and operational risk have been left.

- After a while on July 1997 the Asian financial crisis was happened again because of lax risk management system in banks and financial institutes and also inaccurate monitor of supervisors. Such executive methods extremely damaged monetary systems of different countries and had international consequences (Hemati and MohebiNezhad, 2009). Table 1 shows all kind of risk in banking system and its management (Mehrabi, 2010). 
Table 1. All kind of risk in banking system and its management (Mehrabi, 2010)

\begin{tabular}{ll}
\hline Risk type & Management Method \\
\hline Credit Risk & $\begin{array}{l}\text { Establishing proper loaning structure and required precautions to protect benefits of loaners, applying credit } \\
\text { derivatives by contract of facilities, periodical revisions of bank assets, facilities combination management } \\
\text { because of market events or obtaining extra pledges }\end{array}$ \\
& $\begin{array}{l}\text { Assessment, testing and confirmation of market announced risks including interest rate risk, exchange rate risk, } \\
\text { adjustments risk and current risk }\end{array}$ \\
Market Risk & $\begin{array}{l}\text { Covering the losses resulted from human forces malpractice and ineffectiveness, failure in security practices, } \\
\text { controls and technology, unawareness or incorrectness of information, communication, executive risk of } \\
\text { contracts and by-laws and reputation risk by focusing on controlling mutual operations. The propose of this } \\
\text { control is preventing any infringements on information as well as preventing access of abusers }\end{array}$ \\
& $\begin{array}{l}\text { Estimating cash further requirements of banks. These estimations are done based on three methods: estimation } \\
\text { based on cash resources and expenditures, estimation based on the structure of asses and debts and their } \\
\text { liquidities and estimation based on liquidity standards }\end{array}$ \\
\hline
\end{tabular}

\subsection{Capital Adequacy Matter in Banks' Activities}

Banks fight with losses resulted from non-reimbursement of loans, market bad situations and some operational bottlenecks by their capital. Notwithstanding in best situation it is possible for a bank with proper capital qualification to fall down because of unpleasant events, but many researches such as Grier (2001) addressed reviews which have showed that disaster dimensions of banking crisis were limited in those banks with more proper capital situations. Because a bank with adequate capital has more time to investigate problems and true handle with them. On the other hand capital adequacy of a bank is a relative concept, i.e. being properly of its rate is confirmable by the size and volume of bank activities. So the capital adequacy is determined based on the ratio of capital to assets. This ratio is considered as anindex for bank capability to attract negative effects of contingent losses and return to its proper situation.

Thus the bigger ratio of capital to assets, the higher support for assets by capital or higher capital adequacy against contingent losses. But using this simple ratio to arbitrage about a bank capital adequacy includes limitations with some issues. The most important limitation is that by its through using, it may not be linked the capital rate with the risk rate which bank assets are faced to. On the other hand the simple ratio of capital to assets ignores the structural differences between varies of bank assets. Rose (1988) gave a sample in that the ratio of assets to capitals of two banks of A and B is assumed exactly the same but bank A has invested all its resources on cash assets and short-term governmental guaranteed securities while bank B lent all its resources to private sector. Though it seems that the ratio of capital adequacy of both banks (ration of capital to assets) is equal, but clearly by comparing risks of assets resulted from investment, the capital adequacy of A against contingent risks is so bigger than B. Another limitation is related to conversely effects of determining a compulsory minimum for the simple ratio of capital to assets, i.e. if there is a compulsory minimum and banks are forced to consider that, it will conversely effect on banks' trend to keep cash assets as well as they will prefer to keep more risky profitable assets (such as giving loans and facilities to private sector) than non-risky cash and assets which decrease their liquidities to keep low the maintaining expenditures of compulsory capital. Furthermore according to Gub and Kolari (2005) the lack of a compulsory minimum for simple ratio of capital to assets in 60s and 70s in USA caused decreasing the mentioned ratio to less than 2\% (Pahlevanzadeh, 2007).

\subsection{Liquidity Risk}

Liquidity risk is bank disability to finance for giving loans or in-time payment of its debts (such as deposits). When a bank has not enough cash, it is not able to gain adequate cash quickly and in reasonable cost by increasing debts or converting assets and this disability effects on bank's profitability. In critical conditions the lack of adequate cash could be resulted in bankruptcy of a bank. As all risks are related each other in some way so liquidity risk is also affected by other financial risks such as credit risk, market risk, etc. For example credit risk which is increasing by assets' concentration follows this increment. Similarly defaulting a big loan or changes in exchange rate could put in danger the liquidity situation of a bank. Here it is needed to express some of liquidity risk definitions:

Liquidity risk is bank disability to finance for giving loans or in-time payment of its debts, such as deposits (Tripe, 1999).

This risk is primarily resulted from assets and debts structures and its main origin is from time incompliancy 
with ingoing and outgoing flows; hence liquidity risk could be categorized to two groups of assets liquidity risk and resources liquidity risk (Crouhy and Mark, 2000).

Assets liquidity risk refers to bank disability to sell its assets to meet unexpected cash requirements. Resources liquidity risk also refers to lack of normally attracting resources (such as attracting deposits and/or using banks' facilities and credits) (Asadipoor, 2005).

Liquidity is accessible cash or funds. So it can be said that liquidity risk is the risk of bank unpreparedness for offering loans or in-time repayment of debts (Banks, 2005).

From the other point, liquidity is a characteristic for assets which depends on the time and expenses of its conversion, i.e. the cost of exchanging one asset for cash is a standard to measure liquidity of that asset (Faraji, 2003).

A bank has enough cash when could gain adequate cash through both increasing debts and converting assets to cash in an acceptable rate and cost (Falconer, 2001).

Liquidity risk is also related to non-core funding which including checking accounts, deposit accounts and small time deposits. These accounts are insensitive against difference between banking interests on deposits and market interest rate (Bahrami and AghiliKermani, 2002).

\subsection{Credit Risk}

The simplest definition for credit risk is the probability of taking place a loss in a credit transaction. Michel Crouhy, in Risk Management book, defined credit risk as follow (Rabert and Crouhy, 2001): Non-payment risk is happened following changes in some factors which form credit quality of an asset. According to Basel Committee, credit risk is most simply defined as the potential that a bank borrower or counterparty will fail to meet its obligations in accordance with agreed terms (Hemati and MohebiNezhad, 2009). Credit risk is happened by defaulting/failing of contract party or more generally is happened by a credit event. Historically this risk is generally happened about bonds; i.e. loaners worried about repayment of borrowers, hence sometimes credit risk is also called "default risk".

Credit risk originated from this fact that contract party couldn't or don't want to fulfill contract obligations. The effects of this risk are measured by replacement costs of cash resulted from contract party's default.

Losses resulted from credit risk could be happened before real default of contract party. Generally credit risk could be considered as contingent loss of a credit event. Credit event is happened when the ability of contract party to fulfill his obligations changes. Credit risk is one of the most important factors which create risk in banks and financial companies. This risk results from facilities borrower's disability to repay their debts to bank. To measure credit risk, it should be measured the risk of criteria which could be diversely interpreted: default risk, rate reduction risk, interest rate risk, interest rate variety risk.

\subsection{The Effects of Macro-Economic Factors on Capital Adequacy}

It is so important to identify and control the value and rate of risks for financial and banking sectors. Capital adequacy not only affected by interbank indices but also country's economic conditions. Also two components of GDP growth rate and inflation could reflect cycle performance of banks against economic changes. Mehrara and Mehranfar (2013) showed that there is a negative and significant relationship between inflation rate and capital adequacy ratio because financing costs of bank are increased by inflation rate increment and equity holders asks for higher interest rate, consequently in this situation it is so difficult to increase the capital. Also there is a positive and significant relationship between economic growth and capital adequacy growth. This shows the compatible cycle changes of capital adequacy ratio in country's banking industry. It is simple to explain this result because in economic booms, banks could provide more easily the required capital through financial markets so have more power to fight contingent risks. Besides, in bear market banks should pay more costs for financing and bear more costs to increase capital. As in these situations it is more likely for borrowers to default repayment their loans, banks are not in good conditions and will have not required effectiveness for crisis management.

Adequate capital is one of the most fundamental tools to keep banking system healthy. Any banks and credit institutes should always establish a proper ratio between capital and assets risk. The main function of this ratio is protecting bank against all banking financial and non-financial risks, unexpected losses and also supporting depositors and creditors. It was investigated the relationship between inflation and economic growth rate with capital adequacy by using board data for 15 private and government banks during 2001-2009. The results showed that there is a negative relationship between inflation rate and capital adequacy ratio as well as a positive 
relationship between economic growth rate and capital adequacy ratio (Mehrara and Mehranfar, 2013).

2.5 The Effects of Macro-Economic Factors on Banks' Credit RiskOne of the most important challenges that country's bank system faced to recent years is increasingly development of deferred receivables. This matter has been become a national challenge because of bank-oriented money market of the country and possessing major of cash resources by banks (Borhani, 2010). At the present most of Iran's banks block accounts as deferred receivables; consequently because of increasingly deferred facilities their power to give credit and eventually their income shall be decreased. While the ratio of deferred receivables to facilities has been increased to multiple of acceptable limit (2\%) in some banks (EbrahimiKordlor and Arabi, 2011). Considering mentioned matters, obviously it is so important to identify and investigate effective factors on credit risk of banks and credit institutes because it could prevent loans' defaulting and consequently banking crisis.

The present literature shows that the main effective factor on risk credit is macro-economic factors. For example the research of Keeton and Morris on 2400 commercial banks during 1979-1985 showed that economic situation is the main effective variable on keeping facilities in banking system. Also researchers such as Mueller, Anderson \&Sandaresan and Collin-Dufresne\& Goldstein showed that there is a direct relationship between increasing credit risk level and tough macro-economic situation.

In a research which investigated the relationship between macro-economic variables and credit risk of banks in Iran, the result showed that there is a significant positive relationship between economic growth rate and credit risk of banks. This result approved the results of Davren et al. (2008), Tur, Katherine et al. (2007), Kheminez and Sorina (2005), Copman and Lucas (2003) and Salas and Sorina (2002). Also there is a significant positive relationship between inflation rate and credit risk of banks which is confirmed by the research of Davren et al. (2008). It was found that there is no significant relationship between cash volume and credit risk. Furthermore there is a positive and significant relationship between exchange rate (USD) and credit risk of banks which are confirmed by the researches of Goldstein and Philip Turner (1996) that shows intensive increasing of exchange rate is usually resulted in banking crisis (Saberi and Naderi, 2012). According to the results of variance analysis it can be said that credit risk of Iranian banks has been more affected by macro-economic situation and there is no significant difference between different banks in this matter. Estimation of consolidated data model showed that the variables of GNP growth, GNP volume, import, inflation rate and credit risk of previous period influence credit risk of banks. By comparing partial coefficients of model estimation it can be said that credit risk of previous period had the most influence on credit risk of Iranian banks (Hemati and MohebiNezhad, 2009).

Table 2. Summary of the results of related researches

\begin{tabular}{|c|c|c|}
\hline $\begin{array}{l}\text { Effects of macro-economic variables on bank risk } \\
\text { Researcher and Research Year }\end{array}$ & Variable & Effect manner on risk \\
\hline $\begin{array}{l}\text { Keeton and Morris, } 1987 \text { (2400 commercial banks, } \\
\text { 1979-85) }\end{array}$ & Macro-economic situation & Negative relationship with credit risk \\
\hline \multicolumn{3}{|l|}{ Mueller, Anderson \&Sandaresan, 2000} \\
\hline \multirow{3}{*}{ Mehrara and Mehranfar, 2013 (15 banks, 2000-2008) } & Economic growth rate & Positive relationship with capital adequacy \\
\hline & Inflation rate & Negative relationship with capital adequacy \\
\hline & $\begin{array}{l}\text { Economic growth rate } \\
\text { Inflation }\end{array}$ & Negative relationship with liquidity risk \\
\hline \multirow[t]{2}{*}{$\begin{array}{l}\text { Heidari et al., } 2010 \text { (deferred receivables of banks, } \\
\text { 2000-2008) }\end{array}$} & $\begin{array}{l}\text { GDP growth without } \\
\text { petroleum }\end{array}$ & $\begin{array}{l}\text { Most influence on deferred receivables (credit } \\
\text { risk) }\end{array}$ \\
\hline & Liquidity & \\
\hline \multirow[t]{2}{*}{ Davren et al., 2008} & Economic growth rate & Negative relationship with credit risk \\
\hline & Inflation rate & \\
\hline \multirow[t]{2}{*}{ Morris, Goldstein and Philip Turner (1996) } & Cash volume & Positive relationship with credit risk \\
\hline & Exchange rate & \\
\hline Saberi and Naderi, 2012 & Exchange rate & Positive relationship with banking crisis \\
\hline
\end{tabular}

\section{Research Method}

In this research the theoretical and library studying method was used primarily for studying literature, investigating research history, studying researches and views related to the subject and also finding a proper framework to review the subject. So the subject has been studied by referring to library references include books, 
weekly and monthly journals, quarterly journals, research centers publications, theses and research textbooks, seminars and conferences, electronic databases and literatures.

This research is based on real measures and information of stock exchange, financial statements of listed banks in TSE and also Iran macro-economic data. In this research the financial information was collected from financial statements and explanatory notes of under studied companies and TSE's CDs as well as macro-economic data from year books and time series reports of I.R. of Iran central bank. Eventually the exploited data was categorized and analyzed by statistical analysis software.

Hence it can be summarized that information has been collected from three following references:

A. Financial information TSE listed companies during 2011-2015

B. Official site of stock exchange organization (www.seo.ir)

C. I.R. of Iran central bank site (www.cbi.ir)

From the point of applied data in patterns, it can be generally implied on three patterns:

Time series patterns

Cross-sectional data patters

Patterns which simultaneously used time series and cross-sectional data (consolidated data)

As we used time series data of years between 2011 and 2014 for different sections including listed banks, so it was used consolidated data to analyze data.

\subsection{Research Hypotheses}

There is a significant relationship between macro-economic variables and capital adequacy ratio.

There is a significant relationship between macro-economic variables and liquidity risk.

There is a significant relationship between macro-economic variables and credit risk.

\subsection{Variables and Research Model}

Dependent variable is a response, exogenous and criterion variable; it is an aspect of an organism behavior which has been stimulated. Dependent variable is observed or measured then the effect of independent variable on it shall be clarified (Delavar, 2004: 59). In this research the dependent variables are as follows:

Capital adequacy (KA)

Liquidity risk (LRISK)

Credit risk (CRISK)

This is the inbred driver variable that measured, manipulated or selected by researchers to specify the its influence orrelation with another variable. Independent ad dependent variables are introduction and result, respectively. In an statistic prediction, independent variable is named predictor.

On this basis, independent variables of this research include:

Gross domestic production (GDP)

Petroleum incomes (XOIL)

Cash (M2)

Inflation rate (INFL)

Exchange rate (EXRM)

The model of this research is as follow:

$$
\boldsymbol{Y}_{i}=\boldsymbol{\alpha}_{\mathbf{0} i}+\boldsymbol{\beta}_{1 i}(G D P)+\beta_{2 i}(X O I L)+\beta_{3 i}(M 2)+\beta_{4 i}(I N F L)+\beta_{5 i}(E X R M)+\varepsilon_{0}
$$

\subsection{Analyzing Research Hypotheses}

To analyze research hypotheses it has been firstly tested research variables which are summarized as follows:

\section{Results of Validity Tests for Pattern's Variables}

To render correct presumptions about time series variables, it should be assured about validity of these variables over the time. Ignoring this matter could result in incorrect presumptions about critical quantities of model and gaining a misleading regression. So in this research validity of variables has been tested by Levin's test. The results show in table 3 . 
Table 3. Results of validity test

\begin{tabular}{|c|c|c|c|c|c|}
\hline & Method & Statistic & Prob. ** & Cross-sections & Obs \\
\hline & \multicolumn{5}{|c|}{ Null: Unit root (assumes common unit root process) } \\
\hline KA? & Levin, Lin \& Chu $t^{*}$ & -1.38728 & 0.0427 & 10 & 60 \\
\hline LRISK? & Levin, Lin \& Chu t* & -105.011 & 0.0000 & 10 & 60 \\
\hline CRISK? & Levin, Lin \& Chu $\mathrm{t}^{*}$ & -5.03299 & 0.0000 & 10 & 60 \\
\hline M2? & Levin, Lin \& Chu $t^{*}$ & 28.6961 & 1.0000 & 10 & 60 \\
\hline XOIL? & Levin, Lin \& Chu $\mathrm{t}^{*}$ & -7.91611 & 0.0000 & 10 & 60 \\
\hline GDP? & Levin, Lin \& Chu $t^{*}$ & -2.19021 & 0.0143 & 10 & 60 \\
\hline INFL? & Levin, Lin \& Chu t* & -0.78943 & 0.2149 & 10 & 60 \\
\hline EXRM? & Levin, Lin \& Chu $t^{*}$ & 78.5721 & 1.0000 & 10 & 60 \\
\hline
\end{tabular}

As the results of Levin's test show, capital adequacy, liquidity risk, credit risk and petroleum income variables are from zero point $\left(\mathrm{I}_{0}\right)$ and no need to differencing. But GDP, cash, inflation and stable exchange rate variables are not from zero point so need to differentiation. Hence, according to this matter the Levin's test has been done on these variables by once differencing. The results are showed in following table. As you can see in this table these variables are valid by once differencing, so GDP, cash, inflation and stable exchange rate are from 1 point $\left(\mathrm{I}_{1}\right)$ as well as valid by once differencing.

\subsection{Results of Heteroscedasticitytest}

In conditions that there is a remarkable variation in statistics, ordinary least squares estimators could not be the best. That is if there is heteroscedasticity in data, the ideal method for estimation is the one which attributes less weight to observations with less variation than more variations. Ordinary least squares method doesn't follow this principle and give an equal weight to any observation in time series while in weighted least squares (WLS) or generalized least squares (GLS) difference are strictly considered and present BLUE estimation.

To verify heteroscedasticity in consolidated data model, the variance of different sections are gained by using variance-covariance matrix so that if the elements are on main diameter of matrix, there is heteroscedasticity between sections and weighted least squares estimator is used to remove heteroscedasticity. The mentioned variance-covariance is showed in table 4 ,

Table 4. The results of studying heteroscedasticity

\begin{tabular}{lccccc}
\hline & D(GDP?) & XOIL? & D(D(M2?)) & D(EXRM?) & D(EXRM?) \\
\hline D(GDP?) & $6.53 E-14$ & $-1.11 E-14$ & $-6.20 E-15$ & $4.58 E-13$ & $-5.50 E-09$ \\
XOIL? & $-1.11 E-14$ & $2.01 E-15$ & $1.02 E-15$ & $-7.72 E-14$ & $8.74 E-10$ \\
D(D(M2?)) & $-6.20 E-15$ & $1.02 E-15$ & $6.92 E-16$ & $-4.76 E-14$ & $6.49 E-10$ \\
D(EXRM?) & $4.58 E-13$ & $-7.72 E-14$ & $-4.76 E-14$ & $3.40 E-12$ & $-4.42 E-08$ \\
D(INFL?) & $-5.50 E-09$ & $8.74 E-10$ & $6.49 E-10$ & $-4.42 E-08$ & 0.000732 \\
\hline
\end{tabular}

The results show that the elements on main diameter of variance-covariance matrix are different, so the weights of heteroscedasticity should be considered in any least squares estimations to gain consistent estimator. Hence it may not be used ordinary least squares to estimate the model and we should apply weighted least squares or generalized least squares estimators to avoid estimation bias.

\subsection{Model Estimation}

As you can see in follows, according to above mentioned tests and tests which have been carried out especially for any of models, the model has been done considering dependent variables of capital adequacy, liquidity risk and credit risk. The results of these estimations are presented as follows.

\subsubsection{Estimation of Capital Adequacy Ratio Model}

To estimate the model, first both Chaw's and Hausman's tests were done to investigate whether the model has been done as pool or panel or it is fixed or randomeffects.

\section{A) Results of Chaw test}

To choose a proper model between pool and random effects, Chaw test has been used. The results are shown in 
table 5 .

Table 5. Results of Chaw test

\begin{tabular}{llll}
\hline Effects Test & Statistic & Degree of Freedom & p-value \\
\hline Cross-section F & 54.037003 & $(9,45)$ & 0.0000 \\
Cross-section Chi-square & 148.123591 & 9 & 0.0000 \\
\hline
\end{tabular}

As the statistic is bigger than critical point, so the null hypothesis $\left(\mathrm{H}_{0}\right)$ based on using pool is rejected. So panel data method is used to estimate the model.

B) Results of Hausman test

Hausman test has been use to determine the applied model in consolidated data. This test has been applied to choose between fixed effects or random effects models. The results are shown in table 6 .

Table 6. Results of Hausman test

\begin{tabular}{llll}
\hline & Chi-square Statistic & Degree of Freedom & p-value \\
\hline Cross-section random & 26.614232 & 5 & 0.0001 \\
\hline
\end{tabular}

As the statistic is bigger than critical point and p-value is less than 0.05 , so the $\mathrm{H}_{0}$ hypothesis based on equation of intercepts is rejected. So to estimate the model, fixed effects method is used.

C) Model estimation

According to achieved model in previous sections and according to research hypothesis, the model has been estimated in different sections by using consolidated data method in stationary state as well as fixed effects approach by using weighted least squares regression (generalized):

The results of model estimation are shown in table 7 by using fixed effects approach in sections and using weighted least squares method.

Table 7. Results of model estimation in fixed effects manner in sections and by using weighted least squares method

\begin{tabular}{lllll}
\hline Variable & Coefficient & Standard Error & t-Statistic & Prob. \\
\hline C & 0.086707 & $2.69 \mathrm{E}-15$ & $3.22 \mathrm{E}+13$ & 0.0000 \\
D(GDP?) & $1.19 \mathrm{E}-06$ & $1.19 \mathrm{E}-19$ & $9.96 \mathrm{E}+12$ & 0.0000 \\
XOIL? & $3.70 \mathrm{E}-08$ & $2.67 \mathrm{E}-20$ & $1.39 \mathrm{E}+12$ & 0.0000 \\
D(D(M2?)) & $-1.32 \mathrm{E}-07$ & $1.27 \mathrm{E}-20$ & $-1.03 \mathrm{E}+13$ & 0.0000 \\
D(EXRM?) & $1.09 \mathrm{E}-05$ & $9.69 \mathrm{E}-19$ & $1.12 \mathrm{E}+13$ & 0.0000 \\
D(INFL?) & -0.135862 & $1.60 \mathrm{E}-14$ & $-8.47 \mathrm{E}+12$ & 0.0000 \\
& & & & 0.123194 \\
R-squared & 0.915617 & Mean dependent var & & 0.041819 \\
Adjusted R-squared & 0.889365 & S.D. dependent var & & 0.009920 \\
S.E. of regression & 0.014847 & Sum squared resid & & 1.551548 \\
F-statistic & 34.87734 & Durbin-Watson stat & & \\
Prob(F-statistic) & 0.000000 & & & \\
\hline
\end{tabular}

Also according to regression coefficient table, it is seen that coefficient of determination $\left(\mathrm{R}^{2}\right)$ and generalized $\mathrm{R}^{2}$ have been estimated 0.91 and 0.88 , respectively which show the high explanatory model. As the F-statistic and p-value are equal to 34.87 and 0.00 , respectively, it can be said that the whole model is statistically significant. Furthermore Durbin-Watson statistic shows that there is no autocorrelation in above mentioned model.

\subsection{Estimation of Liquidity Risk Model}

To estimate the model, first both Chaw's and Hausman's tests were done to investigate whether the model has 
been done as pool or panel or it is fixed or randomeffects.

A) Results of Chaw test

To choose a proper model between pool and random effects, Chaw test has been used. The results are shown in table 8 .

Table 8. Results of Chaw test

\begin{tabular}{llll}
\hline Effects Test & Statistic & Degree of Freedom & p-value \\
\hline Cross-section F & 2.008289 & $(9,45)$ & 0.0605 \\
Cross-section Chi-square & 20.259340 & 9 & 0.0164 \\
\hline
\end{tabular}

As the statistic is bigger than critical point, so the null hypothesis $\left(\mathrm{H}_{0}\right)$ based on using pool is rejected. So panel data method is used to estimate the model.

B) Results of Hausman test

Hausman test has been use to determine the applied model in consolidated data. This test has been applied to choose between fixed effects or random effects models. The results are shown in table 9.

Table 9. Results of Hausman test

\begin{tabular}{llll}
\hline & Chi-square Statistic & Degree of Freedom & p-value \\
\hline Cross-section random & 15.967498 & 5 & 0.0031 \\
\hline
\end{tabular}

As the statistic is bigger than critical point and p-value is less than 0.05 , so the $\mathrm{H}_{0}$ hypothesis based on equation of intercepts is rejected. So to estimate the model, fixed effects method is used.

C) Model estimation

According to achieved model in previous sections and according to research hypothesis, the model has been estimated in different sections by using consolidated data method in stationary state as well as fixed effects approach by using weighted least squares regression (generalized):

The results of model estimation are shown in table 10 by using fixed effects approch in sections and using weighted least squares method.

Table 10. Results of model estimation in fixed effects manner in sections and by using weighted least squares method

\begin{tabular}{lllll}
\hline Variable & Coefficient & Standard Error & t-Statistic & Prob. \\
\hline C & 0.024579 & $3.37 \mathrm{E}-16$ & $7.29 \mathrm{E}+13$ & 0.0000 \\
D(GDP?) & $-1.87 \mathrm{E}-06$ & $1.90 \mathrm{E}-20$ & $-9.87 \mathrm{E}+13$ & 0.0000 \\
XOIL? & $3.31 \mathrm{E}-07$ & $4.18 \mathrm{E}-21$ & $7.92 \mathrm{E}+13$ & 0.0000 \\
D(D(M2?)) & $1.55 \mathrm{E}-07$ & $2.06 \mathrm{E}-21$ & $7.52 \mathrm{E}+13$ & 0.0000 \\
D(EXRM?) & $-1.30 \mathrm{E}-05$ & $1.50 \mathrm{E}-19$ & $-8.71 \mathrm{E}+13$ & 0.0000 \\
D(INFL?) & 0.101999 & $2.33 \mathrm{E}-15$ & $4.38 \mathrm{E}+13$ & 0.0000 \\
& & & & 0.036619 \\
R-squared & 0.480810 & Mean dependent var & & 0.040689 \\
Adjusted R-squared & 0.319284 & S.D. dependent var & & 0.047220 \\
S.E. of regression & 0.032394 & Sum squared resid & & 1.994245 \\
F-statistic & 2.976675 & Durbin-Watson stat & & \\
Prob(F-statistic) & 0.002775 & & & \\
\hline
\end{tabular}

Also according to regression coefficient table, it is seen that coefficient of determination $\left(\mathrm{R}^{2}\right)$ and generalized $\mathrm{R}^{2}$ have been estimated 0.48 and 0.31 , respectively which show the high explanatory model. As the F-statistic and p-value are equal to 2.97 and 0.00 , respectively, it can be said that the whole model is statistically significant. Furthermore Durbin-Watson statistic shows that there is no autocorrelation in above mentioned model. 


\subsection{Estimation of Liquidity Risk Model}

To estimate the model, first both Chaw's and Hausman's tests were done to investigate whether the model has been done as pool or panel or it is fixed or randomeffects.

\section{A) Results of Chaw test}

To choose a proper model between pool and random effects, Chaw test has been used. The results are shown in table 11 .

Table 11. Results of Chaw test

\begin{tabular}{llll}
\hline Effects Test & Statistic & Degree of Freedom & p-value \\
\hline Cross-section F & 3.870926 & $(9,45)$ & 0.0011 \\
Cross-section Chi-square & 34.400478 & 9 & 0.0001 \\
\hline
\end{tabular}

As the statistic is bigger than critical point, so the null hypothesis $\left(\mathrm{H}_{0}\right)$ based on using pool is rejected. So panel data method is used to estimate the model.

B) Results of Hausman test

Hausman test has been use to determine the applied model in consolidated data. This test has been applied to choose between fixed effects or random effects models. The results are shown in table 12.

Table 12. Results of Hausman test

\begin{tabular}{llll}
\hline & Chi-square Statistic & Degree of Freedom & p-value \\
\hline Cross-section random & 12.829468 & 5 & 0.0121 \\
\hline
\end{tabular}

As the statistic is bigger than critical point and p-value is less than 0.05 , so the $\mathrm{H}_{0}$ hypothesis based on equation of intercepts is rejected. So to estimate the model, fixed effects method is used.

C) Model estimation

According to achieved model in previous sections and according to research hypothesis, the model has been estimated in different sections by using consolidated data method in stationary state as well as fixed effects approach by using weighted least squares regression (generalized):

The results of model estimation are shown in table 13 by using fixed effects approach in sections and using weighted least squares method.

Table 13. Results of model estimation in fixed effects manner in sections and by using weighted least squares method

\begin{tabular}{lllll}
\hline Variable & Coefficient & Standard Error & t-Statistic & Prob. \\
\hline C & 0.015639 & $1.96 \mathrm{E}-16$ & $7.98 \mathrm{E}+13$ & 0.0000 \\
D(GDP?) & $-4.30 \mathrm{E}-07$ & $1.02 \mathrm{E}-20$ & $-4.23 \mathrm{E}+13$ & 0.0000 \\
XOIL? & $3.07 \mathrm{E}-08$ & $2.02 \mathrm{E}-21$ & $1.52 \mathrm{E}+13$ & 0.0000 \\
D(D(M2?)) & $5.71 \mathrm{E}-08$ & $1.08 \mathrm{E}-21$ & $5.31 \mathrm{E}+13$ & 0.0000 \\
D(EXRM?) & $-4.02 \mathrm{E}-06$ & $8.16 \mathrm{E}-20$ & $-4.93 \mathrm{E}+13$ & 0.0000 \\
D(INFL?) & 0.056070 & $1.31 \mathrm{E}-15$ & $4.29 \mathrm{E}+13$ & 0.0000 \\
& & & & 0.016599 \\
R-squared & 0.706116 & Mean dependent var & & 0.016015 \\
Adjusted R-squared & 0.614686 & S.D. dependent var & & 0.000939 \\
S.E. of regression & 0.004568 & Sum squared resid & & 1.997511 \\
F-statistic & 7.722982 & Durbin-Watson stat & & \\
Prob(F-statistic) & 0.000000 & & & \\
\hline
\end{tabular}

Also according to regression coefficient table, it is seen that coefficient of determination $\left(\mathrm{R}^{2}\right)$ and generalized $\mathrm{R}^{2}$ have been estimated 0.70 and 0.61 , respectively which show the high explanatory model. As the F-statistic and 
p-value are equal to 7.72 and 0.00 , respectively, it can be said that the whole model is statistically significant. Furthermore Durbin-Watson statistic shows that there is no autocorrelation in above mentioned model.

\section{Discussion and Conclusion}

Iranian banks play a key role in financing economic enterprises in absence of extensive capital market. On the other hand banks are considered as driver engine of economic growth and development and they can be directly or indirectly affected by any inefficiency and disorders resulted from disfavor economic situation. Recent cash volume growth and other effective variables on monetary basis caused increasing inflation rate and disfavor effects on economic and eventually on banking system. On the other hand in Iran's economics, according to money market mechanism the increasing cash volume resulted in increasing demand for money speculative in certain level of income. Severe fluctuation of gold and currency markets during last year is an obvious sample of increasing demand for money speculative.

By increasing inflation, operating and non-operating expenses of banks are simultaneously increased while applicants for facilities also will be faced unexpected costs because by increasing expenses of operations, banks will pay new facilities to applicants with higher rates to keep their profit margin.

About increasing operational expenses, it can be argued than when interest rate of deposits is less than inflation rate, depositors don't trend to deposit in banks as the inflation decreased their purchasing power and money value; so if interest of deposits is less than inflation rate, actually the value of depositors' money in bank is decreased and shall be moved to more attractive and profitable markets such as real estate, currency and gold. It should be noted that the duration of having money is limited for customers and this money shall be finally returned to banking network. Then inflation has not independently influence on increasing or decreasing banks' funds and just results in changing combination and ratio of investment deposits. In this matter it is possible to decrease long term investment deposits and increase checking and short term deposits. In this course decreasing long term investment deposits in favor of checking and short term deposits indicates decreasing power of forming fund because the influence of time deposits growth on investment is more significant than demand deposits growth as well as banks could pay long term facilities from time deposits to finance investment projects.

During last years, Iran's economics has been faced high liquidity level because of some reasons such as increasing net foreign assets of central bank, increasing net liabilities of public sector, public budget deficit, overreliance of economics to petroleum incomes, independency of central bank and financial-monetary expansionary policies. And also this picture that economics' problems such as inflation, joblessness and other issues could be solved by using banking credits and put pressures on banking network is one of the important and effective factors in liquidity growth and made some problems for banking network.

In this matter according to the current economic situation of Iran such as high profitability of markets like real estate, currency or gold, central bank - to prevent running resources toward business activities - could determine banking interest rate more flexible and in short time sections (for example quarterly) besides adopting policies to control inflation with changing its' approach in determining annual interest rate of deposits (in a policy-monitoring package).

\section{References}

Ahmadian, A. A. (2012). Credit risk management, challenges of financing in Iranian banking system (3rd ed.). International Conference of Construction Industry.

Akhavani, M. (2007). Liquidity risk modeling of EghtesadNovin Bank. MA thesis, Tehran University

Anderson, R., \&Sandaresan, S. (2000). A Comparative Study of Structural Models of Corporate Bond Yields: An Explanatory Investigation. Journal of Banking \& Finance, 24, 255-69.

Ansari, A. et al (1995). Foreign physical capitals and methods of attracting them. Tehran, Ministry of Economic and Finance Affairs.

Arab, M. A., \& Ghanbari, H. (1997). Theoretical fundamentals of liquidity management in banks. Tehran, Lectures and articles of $8^{\text {th }}$ Islamic Banking Seminar

Asadipoor, N. (2005). Reviewing the role and importance of risk-orientation monitoring in banking supervision and comparing with comparative supervision. MA thesis, Tehran; Banking Sciences Institute

Bahrami, M., \& AghiliKermani. (2002). Articles of $13^{\text {th }}$ Congress of Islamic Banking, Risk management in Islamic banking. Tehran, Iran Supreme Institute of Banking.

Banks, E. (2005). Liquidity Risk Managing Asset and Funding Risk, Palgrave Macmillan. 
Barzandeh, M., and Hosseinin, R. (2001). Introduction to risk management and relevant consepts. Keshavarzi Bank Quarterly Journal, 2, 125-139

Bokpin G. A. (2009). Macroeconomic Development and Capital Structure Decisions of Firms. Studies in Economics and Finance, 26(2), 129-142.

Borhani, H. (2010). Reviewing the reasons of making outstanding receivables and its' decreasing solutions. Tehran, $21^{\text {st }}$ Congress of Islamic Banking

Castro, V. (2013). Macroeconomic determinants of the credit risk in the banking system: The case of the GIPSI. Economic Modeling, 31, 672-683.

Crouhy, M., Galai, D., \& Mark, R. (2000). A comparative analysis of current credit risk models. Journal of Banking and Finance, 24(1-2), 59-117.

Da Silva, Marcos, S., \& Divino, J. A. (2013). The role of banking regulation in an economy under credit risk and liquidity shock. North American Journal of Economics and Finance, available at SciVerse Science Direct.

Davani, G. (2005). Stock Exchange, Stocks and Stock Pricing. Tehran, Tasvir publication

Dergregorian, S. (2004). Planning the model of liquidity risk measurement for Iran private banking system (case study: Saman bank). MA thesis, Tehran, ShahidBeheshti University

Economic Reviews Dept. (2004). The effects of equilibrium exchange rate on macro-variables. Researches centers; Research deputy; Serial No. 6775; subject code: 240

EghtesadNovin Bank. (2008). Development project of risk management software of studies and risk management group of EghtesadNovin bank; asset-liability management and liquidity risk in financial institutes; Tehran, FaraSokhan publication

Falconer, B. (2001). Structural Liquidity: The Worry Beneath The Surface. Balance Sheet, 9(3), 13-19.

Fanelli J. M., \& Keifman, S. (2002). Finance and Changing Patterns in Developing Countries. Journal of Finance and Accounting, 15(4), 143-171.

Faraji, Y. (2003). Introduction with monetary-financial tools and institutes. Tehran; Iran Supreme Institute of Banking.

Fischer, S. (1988). Real Balances, the Exchange Rate, and Indexation: Real Variables in Disinflation. Quarterly Journal of Economics, 103.

Gavin, M., \& Haussmann, R. (1996). The Roots of Banking Crises: The Macroeconomic Context. Inter-American Bank, Working Paper, 318, 1-20.

Goldstein, M., \& Turner, P. (1996). Banking Crises in Emerging Economies.

Greuning, H., \& Bratanovic, S. B. (2003). Analyzing and Managing Banking Risk, Washington, D. C. The World Bank.

Hansjorg, L., \& Michael, M. (2006). The Exposure of Swiss Banks to Macroeconomic Shocks-an Empirical Investigation. Swiss National Bank.

Heidary, H.et al. (2010). Reviewing the effects of macro-economic indices in outstanding receivables of banks. Money and Economic Quarterly Journal, 4, 192-219

Hemati, A., \& MohebiNezhad, S. (2009). Investigating the effects of macro-economic variables on credit risk of banks. Economic research letter; Winter, 33-59.

Ibrahim, M. H. (1999). Macroeconomic Variables and Stock prices in Malaysia: An Empirical Analysis. Asian Economic Journal, 13, 219-231.

Jahankhani, A., \& Parsaian, A. (1996). Tehran Stock Exchange, Tehran University publication.

Jama'at, A., \& Asgari, F. (2010). Credit risk management in banking system with data mining approach. Qualification Studies in Management, 1(3): 115-126.

Karami, Mostafa (2010). Presenting a model to assess credit risk situation of customers before giving banking facilities. Saderat bank, 10; Sinter 2009 and Spring 2010; Nos. 50 and 51

Karimkhani, A., \& Forati, M. (2012). Reviewing the effects of macro-economic variables on banks' resources and applications"; Risk research and control Dept.; Sepah bank.

Keeton, W. R., \& Morris, C. S. (1987), Why Do Banks Loan Losses Differ? Federal Reserve Bank of Kansas 
City Economic Review, 3-21.

Khavari, M. R. (2011). A pattern for validation and credit ranking of banks' customers. $15^{\text {th }}$ Congress of Islamic Banking; comprehensive portal of human sciences.

Kimiagari, M., Amini, M. J., TabatabaieArani, H., \& Hosseini, L. (2012). The model of credit risk of facilities repayment of credit customers (Case study: Melli Iran bank, Shahreza branch). $9^{\text {th }}$ International Conference of Industries engineering.

Kordlar, A., \& Arabi, M. (2011). Reviewing the function of bankruptcy prediction models (Altman, Falmer, Springit, Zimesky and Shirata) in forecasting facilities default to listed companies of TSE. Accounting and auditing researches; 12

Management Advisors Group of Comprehensive Path Plan. (2013). Definition and manner of calculating banking risks; Briefly reviewing of modern topics in organization and management theories; study field: Organization and management theories.

Mehrabi, L. (2010). Risk management in interest-free banking system (emphasizing on credit risk). Economic news, 8(130), 70-77.

Mehrara, M., \& Mehranfar, M. (2013); "Banking operation and macro-economic factors in risk management. Economic Modeling Quarterly Journal, 7(1), 21-37.

Michaeilpoor, H., \& Shiva, R. (2003). Risk management in banking field. articles of $14^{\text {th }}$ Congress of Islamic Banking.

Miller, K., \& Show Fang, G. (2001). Is There a Long-Run Relationship between Stock Returns and Monetary Variables: Evidence from an Emerging Market. Applied Financial Economics, Vol. 11, PP. 641-649.

Moosaei, M. et al. (2010). The relationship between stock market and macro-economic variables in Iran. Economic Researches and Politics Quarterly Journal, 8(54), 73-94.

Morley, B., \& Pentecost, E. J. (2000). Common Trends and Cycles in G7 Countries Exchange Rates and Stock Prices. Applied Economic Letters, 7, 7-10.

Moshrefi, G. (2005). Review of reasons of stock exchange fluctuations (Stock exchange position in macro-econoics). Tadbir monthly journal; Nos. 160-1.

Mueller, C. (2000). A Simple Multi-factor Model of Corporate Bond Prices. Doctoral Dissertation, University of Wisconsid-Madison.

Ngurah, I., Gusti, M., Narindra, N., Catharina, B., \& RianPraktikto, F. (2012). Assessing Credit Risk: An Application of Data Mining in a Rural Bank. Procedia Economics and Finance, 4, 406-412.

Pahlevan, Z. M. (2007). A review to new approach of capital adequacy ratio in banks (based on $2^{\text {nd }}$ manifest of Basel Committee on Banking Supervision); Human Sciences and Cultural Studies Research Institute; Comprehensive portal of human sciences; Nos. 52 and 53

Radpoor, M. (2011). A mechanism for credit risk measurement and management of Iran banks. Financial and investment articles (second volume); Iran Financial Education website

Rahmani, T. (2001). Macro-Economics.

Reut Institute. (n.d.). (2012). Macroeconomic Stability. Retrieved, April 31. fromhttp://www.reut-institute.org/en

Rostamian, F., Haji, B., \& Fatemeh. (2009).Liquidity risk measurement of banks by using the model of value exposed in danger (case study: Saman bank). Financial accounting and auditing research magazine; pp 175-198

Roueintan, P. (2005). Reviewing effective factors on credit risk of bank's legal customers (case study: Keshavarzi bank). Economic and politic sciences faculty; ShahidBeheshti university

Sahay, R., \& Goyal, R. (2006). Volatility and Growth in Latin America. IMF Working Paper.

Sajadi, H. et al. (2010). Reviewing the relationship between macro-economic variables and stock return index in TSE.

Sameti, M. et al. (2005). Government financial imbalance and inflation rate in Iran. Iran Economic Researches Quarterly Journal, 7(24).

Taghavi, M. (2010). Assessment and submitting a proper pattern for identifying, measuring and controlling financial risks in financial and credit institute (Case Study: Mellat Bank). Management Researches, 21(86), 
$1-10$

Van Roy, P. (2005). The Impact of the 1988 Basle Accord on Bank's Capital Ratios and Credit Risk Taking: An International Study. European Center for Advanced Research in Economics and Statistics (ECARES) Av. F. D. Roosevelt, Brussels, Belgium.

Wood, W., \& Walter, G. (1968). Bank Liquidity Management: Theories and techniques. Bankers Magazine, CL 4, 66-78.

\section{Copyrights}

Copyright for this article is retained by the author(s), with first publication rights granted to the journal.

This is an open-access article distributed under the terms and conditions of the Creative Commons Attribution license (http://creativecommons.org/licenses/by/4.0/). 